\title{
Anesthesia Mumps; A Rare Complication After Surgery
}

\section{Anestezi Kabakulak; Ameliyat Sonrası Nadir Görülen Bir Komplikasyon}

\author{
CGüner Yurtsever1, @Ejder Saylav Bora', @Mustafa Ercan Günel² \\ İzmir Katip Çelebi University Atatürk Research and Training Hospital Department of Emergency, İzmir, Turkey \\ 2ízmir Bakırçay University Çiğli Research and Training Hospital, İzmir, Turkey
}

\begin{abstract}
Anesthesia mumps is a rare complication that occurs with sudden swelling of the parotid gland, especially after surgery. It regresses without sequelae within days with symptomatic treatment or spontaneously. It is thought that it may be due to vasodilation, hyperemia, air leakage into the stenone duct, perioperative use of drugs such as atropine, succinylcholine, morphine, and propofol, and the posture position of the patient in the operation. Anesthesia mumps appears within the first few weeks after the operation. In this article, we presented the complication that developed in the event of a short-term procedure such as double $\mathrm{J}$ catheter removal.
\end{abstract}

Keywords: Emergency service, parotid gland swelling, anesthesia mumps, postoperative complications.

\section{INTRODUCTION}

Anesthesia mumps is a rare complication that occurs with sudden swelling of the parotid gland, especially after surgery. ${ }^{[1]}$ It can show unilateral or bilateral involvement and is mostly painless. It regresses without sequelae within days with symptomatic treatment or spontaneously. ${ }^{[1,2]}$ The etiology of anesthesia mumps is unclear, although there are different mechanisms reported. Vasodilation, hyperemia, air leakage into the stenone duct, perioperative use of drugs such as atropine, succinylcholine, morphine, and propofol may ocur. ${ }^{[3]}$ It is also thought that it may depend on the patient's posture during the operation. Anesthesia mumps appears within the first few weeks after the operation. ${ }^{[4]}$ It was first reported in 1968 after various surgical procedures. ${ }^{[4]}$ Although there are publications on this subject from Surgical Clinics and anesthesia ${ }^{[4,7,11]}$ we observed that there were no reports from the emergency department regarding postoperative parotid gland swelling. In this article, bilateral

\section{Öz}

Anestezi kabakulak özellikle ameliyat sonrası parotis bezinin ani şişmesi ile meydana gelen nadir bir komplikasyondur. Semptomatik tedavi veya kendiliğinden günler içerisinde sekel bırakmadan gerilemektedir. Vazodilatasyon, hiperemi, stenon kanalına hava kaçması, perioperatif atropin, süksinilkolin, morfin, propofol gibi ilaçların kullanımı sonucu ve hastanın operasyondaki duruş pozisyonuna bağlı olabileceği düşünülmektedir. Anestezi kabakulak operasyondan sonra ilk birkaç hafta içinde ortaya çıkar. Bu yazı da double j kateter çıkarılması gibi kısa süreli bir işlemin akşamı gelişen komplikasyonu sunduk.

Anahtar Kelimeler: Acil servis, parotis bezi şişmesi, anestezi kabakulak, postoperatif komplikasyonlar

parotid gland swelling is presented after double $\mathrm{J}$ catheter intervention (without intubation); This is one of the rare cases of anesthesia mumps in the Emergency Medicine literature.

\section{CASE}

A 43-year-old female patient was admitted to the emergency department with sudden swelling behind both ears. The patient stated that she was receiving continuous antihistamine therapy due to chronic urticaria.

In the morning of the same day, the double J catheter attached to her kidney due to nephrolithiasis was removed. It was learned that the patient had no other medication use during the day and no medication was given other than propofol for sedation. A total $200 \mathrm{mg}$ propofol $1 \mathrm{mg} /$ $\mathrm{kg}$ dose, $100 \mathrm{mg}$ IV loading dose in 3 minutes and repeated 
doses of $0.5 \mathrm{mg} / \mathrm{kg} 2$ times with 3 minutes intervals were administered. Ramsey scale was 3 during the procedure. The patient vital signs was monitored before, during, and after the procedure.

There was no pathological feature in our patient's laboratory findings. Edema was detected in both parotid glands on ultrasound imaging.

The patient was diagnosed with anesthesia mumps, which is a rare side effect after sedation. Hydration was given to the patient by taking the opinion of the anesthesia clinic. After 3000 cc of hydration and analgesic application, the patient was discharged with hydration recommendations, as her complaints regressed (Figure).

\section{DISCUSSION}

Swelling of the parotid gland during or after surgery is a known but rare side effect. Although there are cases published by surgery and anesthesia clinics on this subject, we observed that there are no reports from emergency services regarding postoperative swelling of the parotid gland.

The etiology of anesthesia mumps is still unclear, despite different mechanisms reported. It is thought that breathing with a positive pressure mask may cause an increase in head and neck tone (positional problems), strain and cough, decrease in venous drainage and reverse air flow through the stenone duct. $^{[5]}$ In order to prevent this situation, it is recommended to prevent the compression of the parotid gland or duct by providing the patient with an appropriate position during the operation. ${ }^{[4]}$ Another view is thought to be due to the vascular contraction effects of parasympathetic drugs. ${ }^{[6]}$ Salivary gland enlargement; It has been identified as a unique side effect of many drugs, including analgesics, anti-histamines, muscle relaxants (succinylcholine), sedatives, and phenothiazine derivatives. ${ }^{[7-10]}$ Atropine may play a role in parotid gland enlargement by causing stenosis of the salivary glands, causing thick and viscous saliva. ${ }^{[10]}$ Preoperative dehydration is thought to cause more intense secretion and predispose to salivary duct obstruction. ${ }^{[11,12]}$ In addition, it may cause mechanical obstruction of the parotid canal with fixation of the endotracheal tube after intubation or the inability to evacuate the secretion and temporary parotid gland enlargement due to the traumatization of the parotid canal. ${ }^{[13]}$

Unfortunately, since the exact cause is not known, there is no method that can prevent the development of anesthesia mumps and treat it directly. Treatment methods in anesthesia mumps mostly include hydration and pain monitoring. Since our patient had chronic urticaria, she frequently used antihistamine medication. In this case, we think that the main factor that triggers anesthesia mumps is the application of propofol (which is frequently used for sedation in the emergency room) during the operation and as she often use antihistaminic and the decrease in the secretions because of propofol, ${ }^{[14]}$ the patient suffer from anesthesia mumps.

Anesthesia mumps can regress in a few days with abundant hydration, symptomatic treatment or no treatment. However, anesthesia mumps should definitely come to our mind in the differential diagnosis of parotitis.

\section{CONCLUSION}

Anesthesia mumps is a rare and self-limiting postoperative complication. Usually anti-inflammatory medications go away within a few days with adequate hydration.

We believe that questioning the operation history in the last few weeks in patients presenting to the emergency department with parotid gland swelling may be helpful in the diagnosis of the patients.

\section{ETHICAL CONSIDERATIONS}

Informed Consent: Written informed consent was obtained from all participants who participated in this study.

Status of Peer-review: Externally peer-reviewed.

Conflict of Interest Statement: The authors have no conflicts of interest to declare.

Financial Disclosure: The authors declared that this study has received no financial support.

Author Contributions: All of the authors declare that they have all participated in the design, execution, and analysis of the paper, and that they have approved the final version.
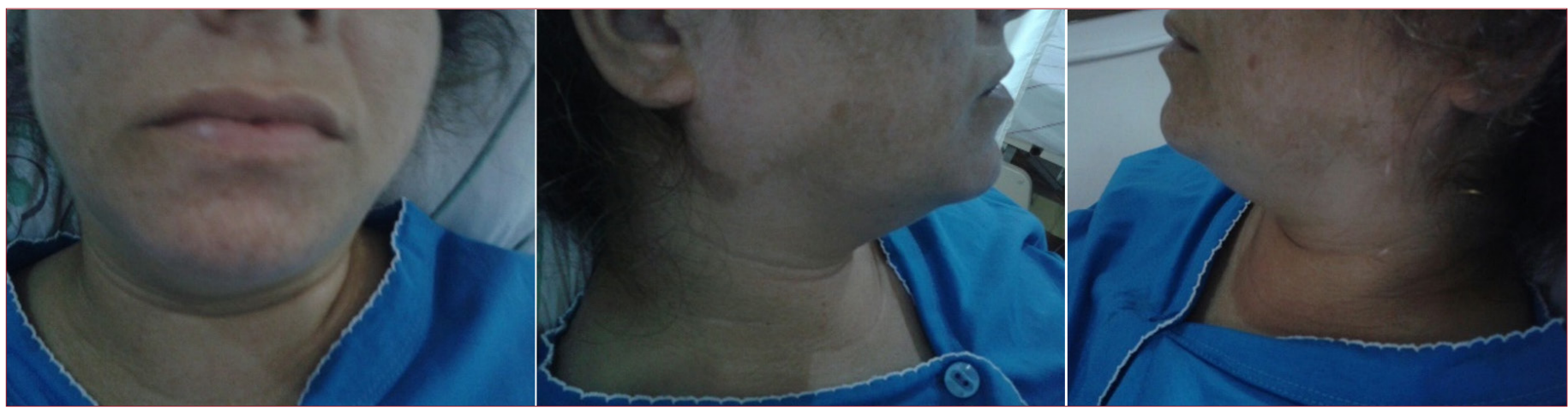

Figure. Images of the relevant case 


\section{REFERENCES}

1. Serin S, Kaya S, Kara CO, Baser S. A case of anesthesia mumps. Anesth Analg 2007;104:1005.

2. Narang D, Trikha A, Chandralekha C. Anethesia mumps and Morbit obesity. Acta Anaesthesiol Belg; 2010;6:83-5.

3. Mandel L, Surattanont F. Bilateral parotid swelling : a review. Oral Surg Oral Med Oral Pathol Oral Radiol Endod 2002;93:221-37.

4. Kaya C, SEKBAN N, ÖZTÜRK S, GENCER M. Postoperatif Parotitis; Olgu Sunumu Eşliğinde Literatüre Genel Bir Bakış Turkiye Klinikleri J Anest Reanim 2013;11(2):79-82

5. Attas M, Sabawala PB, Keats AS. Acute transient sialadenopathy during induction of anesthesia. Anesthesiology 1968;29:1050-2.

6. Bonchek LI. Salivary gland enlargement during induction of anesthesia. JAMA. 1969; 209:1716-8.

7. Gilsanz F, Alvarez J, Martinez R, Vaquero J Transient parotid gland swelling after neurosurgical procedures. J Neurosurg Sci. 1988;32:123-5

8. Kimura H, Watanabe $Y$, Mizukoshi K, Yamamoto $Y$, Araki S Six cases of anesthesia mumps. Nippon Jibiinkoka Gakkai Kaiho. 1993;96:1915-21.

9. Rice DH Saliva gland physiology. Otolaryngol Clin North Am 1977;10:27385

10. Rubin MM, Cozzi G, Meadow E. Acute transient sialadenopathy associated with anesthesia. Oral Surg Oral Med Oral Pathol 1986;61:227-9.

11. Shields HM, Soloway RD, Long WB et al Bilateral recurrent parotid swelling after endoscopy Gastroenterology. 1977;73:164-5.

12. Slaughter RL Parotid gland swelling developing during peroral endoscopy. Gastrointest Endosc 1975;22:38-9.

13. Wakayama S Salivary gland swelling developing during and immediately after general anesthesia. Anesthesiology. 1968;22:14-17. (in Japanese)

14. Morse Z, Sano K, Kanri T. Decreased intraoral secretions during sedation-analgesia with propofol-ketamine and midazolam-ketamine combinations. J Anesth 2001;15(4):197-200. 